\title{
Junto Diaz's The Brief Wondrous Life of Oscar Wao: A Narrative of Identity and Diaspora
}

\author{
Samirah Almutairi \\ Independent Researcher \\ Salahuddin, Riyadh 12435. Saudi Arabia
}

\begin{abstract}
Junto Diaz's novel The Brief Wondrous Life of Oscar Wao raises the question of the identity formation for the Caribbean in diaspora. Diasporic Caribbean people struggle with understanding their difference and recognizing the important of assimilating to other people's lives and cultures when they leave their home country. The struggle of the main character, Oscar Wao, in the novel is established perfectly well through apparent identity crisis that is manifested in his cultural displacements, childhood memories, real-life situations, and unsuccessful relationship with the other sex. It is a problem that Oscar creates his passage towards constructing a national identity, which ends in a tragic death. Caribbean people should privilege a hybrid identify if they want to live outside the West Indies. The present article aims to analyze from a postcolonial perspective Oscar's futile search for national identity in diaspora and its consequences. This is clarified through a discussion of migration, the results of living in diaspora on the identity formation for the main character, relationships with women, and the concept of a return to the homeland.
\end{abstract}

Keywords: Assimilation, diaspora, hybrid identity, national identity, The Brief Wondrous Life of Oscar Wao

Cite as: Almutairi, S. (2020). Junto Diaz's The Brief Wondrous Life of Oscar Wao: A Narrative of Identity and Diaspora. Arab World English Journal for Translation \& Literary Studies 4 (4) 202-212. DOI: http://dx.doi.org/10.24093/awejtls/vol4no4.14 


\section{Introduction}

After the Second World War and around the middle of the twentieth century, a massive number of colonies in the West Indies, African and India gained their political independence. Moreover, a large group of writers has proffered a new and unique type of literature that reflected the general atmosphere of postcolonialism. Padley (2006) said: " nations that were emerging out of their colonial past were intent on establishing their own national and cultural identities. One of the main ways in which they did was through literature" (p.122). This literature raises questions about colonization, imperialism, power relations, and human rights. Hence, it is called postcolonial literature. Postcolonial texts are concerned with the multiple atrocities and violence Third World countries and societies went through, question the imbalance of power relationships, and call for implementing justice and full freedom all over the world.

Because the West Indies were former colonies, most of the Caribbean literature is characterized as postcolonial literature. Some of these texts are written either in English or French, hence called Anglophone and Francophone Caribbean literature. Caribbean writers have written unique literature that speaks about their particular colonial situation, culture, and heritage. Phillips (2001) noted about the Caribbean literature in an interview:

The great strength of Caribbean literature has been its lack of national, and to a large extent international, borders. It's enabled it to grow outside too. Surely Caribbean migration means that 'here' is pretty much everywhere, and I'm not just talking about postwar migration. I mean Rhys, CLR [James], etc. ... I often feel that other countries with 'strong' national literatures- Britain, France, USA, Canada- are increasingly looking to the micro-model of Caribbean literature to see how you can still have a coherent 'national' literature that rises up above geography. It doesn't seem to me that now is the time for Caribbean literature to start retreating to clumsy and reductive essentialism and door-slamming. It's only a strong and self-confident literature that can operate with the door open and ajar. (as cited in O'Callaghan, 2010, p. 28).

Writers such as Derek Walcott, Jamaica Kincaid, Patrick Chamoiseau, Junot Diaz, and Ezekel Alan have written remarkable poems, plays, and novels that describe the postcolonial situation of the Caribbean culture and people.

Interestingly enough, critics have studied these postcolonial literary texts and examined their political, social, literal, and ideological dimensions. They continue to echo the voices found in postcolonial literature, investigate the colonial stereotypes, and reread the European literary texts. One of the most complex issues that are repeatedly mentioned in postcolonial criticism of Caribbean literature is the concept of identity formation for the Caribbean and the impact of colonization on their identities. In postcolonial theory, the word "identity" is sometimes mentioned along with words such as "culture", "crisis", "formation", and "negotiating". This shows to a great extent that the concept of identity is highly problematic and multidimensional.

Said (1993) the Palestinian-American critic, triggered the concept of identity concerning culture. He believed that culture is sometimes identified as identity. "Culture comes to be 
associated, often aggressively, with the nation or the state, this differentiates "us" from "them" ... Culture in this sense is a source of identity" (p. xiii). He argued that the idea of connecting culture to identity does not endorse postmodern philosophies such as diversity and hybridity. According to Said (1993), it is implausible for a postcolonial nation to have a pure ethnicity and one singular national culture. "No identity can ever exist by itself or without an array of opposites, negatives, and oppositions" (p.52). He added as an irrefutable fact that imperialism causes a mixture of cultures and identities. Imperialism indeed promotes categorizations such as white, or Black, Western, or Oriental. Postcolonialism, on the contrary, deconstructs binary oppositions such as superior-master and inferior-slave relationships. He explained:

No one today is purely one thing ... Imperialism consolidated the mixture of cultures and identities on a global scale. But its worst and most paradoxical gift was to allow people to believe that were only, mainly exclusively, white, or Black or, Western, or Oriental. Human beings make their own history, they also make their cultures and ethnic identities. No one can deny the persisting continuities of long traditions, sustained habitations, national languages, and cultural geographies, but there seems no reason except fear and prejudice to keep insisting on their separation and distinctiveness, as if that was all human life was about. (p.336)

In Said's footsteps, there followed a group of critics who wrote about identity in postcolonial texts. Among the critics who examined the concept of identity are the Jamaican- British cultural theorist and socialist Stuart Hall and H. Adlai Murdoch. Hall (1995a) examined, in particular, the concept of identity in the Caribbean. In his article "Negotiating Caribbean Identities", he argued that "identity presenting itself always as a problem to Caribbean people" (p.3). He commented that the situation of the Caribbean is more problematic and unique because of the disappearance of the original inhabitants (Arawaks and Caribs) after the European encounter and the displacement of the slaves who were brought to the West Indies from Africa to work in the plantation fields. Presently, the Caribbean Islands are places for immigrants from all over the world and groups who seek work and labor.

Hall (1995a) also declared that "the Caribbean is the first, the original and the purest diaspora" (p.6). It entails that the Caribbean islands are not the mother country for the Caribbean people because the islands are inhabited by many people who originally don't belong to the Islands. The consistent change and transformations that happened to the Caribbean, which is being mixed with others' origins and cultures, do not allow them to construct national identities for themselves. It is difficult for the Caribbean to retain the old customs and habits from their lost ancestors. Consequently, the concept of the Caribbean identity should be situated within the unique situation of the Caribbean people. Murdoch (2007) also examined the diasporic situation of the Caribbean and argues that "it is precisely here that the unfixed, heterogeneous character of Caribbean identitythe product of a cross-cultural influences irrevocably resistant to suggested singularities of location and temporality- encounters the constructed, nonoriginary nature of identity in its postmodern, poststructuralist guise" (p.578).

Arab World English Journal for Translation \& Literary Studies

ISSN: 2550-1542 | www.awej-tls.org 
The recognition of the diasporic nature and the differences of the Caribbean ethnic groups and culture shows to a great extent that the Caribbean cannot form a singular national Caribbean identity. Hybrid identity should be more privileged to the Caribbean. Edwards (2003) pointed that:

Diaspora points to difference not only internally (the ways transnational black groupings are fractured by nation, class, gender, sexuality, and language) but also externally [...] we are forced to think not in terms of some closed or autonomous system of African dispersal but explicitly in terms of complex past of forced migration and racialization (qtd. in Murdoch, 2007, p.578).

Moreover, Hall (1995a) believed that diasporic societies go through difficult processes of understanding and discerning their multiple cultures. These processes include "assimilation", "translation", "adaptation", "resistance", and" reselection" (p.7). Diasporic people construct their identities based on their diverse cultures and experiences. Hall (1990) pointed out that:

The diaspora experience as [he] intend[s] it here is defined not by essence or purity, but by the recognition of a necessary heterogeneity and diversity; by a conception of 'identity' which lives with and through, not despite, difference; by hybridity. Diaspora identities are those which are constantly producing and reproducing themselves anew, through transformation and difference. (p.235)

Hall (1990) maintained that the Caribbean is "the space where the creolisations and assimilations and syncretisms were negotiated" (p. 234). Given that conclusion, the Caribbean cannot form a national identity inside and outside the Caribbean island because syncretic models characterize their culture, language, and lives everywhere. The idea of a return to origins is romanticized and futile. Hall (1990) expressed that:

It is because this New World is constituted for us place, a narrative of displacement, that is gives rise to profoundly to a certain imaginary plentitude, recreating the endless desire to return to 'lost origins', to be one again with the mother, to go back to the beginning ... And yet, this return to the beginning is like the imaginary in Lacan-it is neither be fulfilled no requited, and hence is the beginning of the symbolic, of representation, the infinitely renewable source of desire, memory. Myth, search, discovery.

(p. 236)

\section{Analysis}

Interestingly enough, most of the Caribbean novels address the problem and the complexity of identity for the Caribbean and portrait the diasporic experience of the Caribbean people. For example, Junot Diaz's The Brief Wondrous Life of Oscar Wao (2008) can be categorized as a narrative of diaspora with questions of national identity formation for the Caribbean. The novel tackles the attempts of the main character to construct a national identity in diaspora. To explain, Oscar Wao's family comes from the Dominican Republic. Oscar's mother migrated to the United 
States of America. The novel describes the hardship of the history the protagonist and his family or ancestors went through in their motherland, which caused them to migrate. In the novel, migration deepens their main diasporic experience and fragmentation. Instead of assimilating to the culture of the United State and responding to his diasporic nature to form a hybrid identity, Oscar insists on constructing a national identity for himself, which results in a life full of difficulty and problems. He returns to his homeland and place of origin and unfortunately faces death. The present article aims to analyze from a postcolonial perspective the attempts of the protagonist to form a national identity. The futility to form a national identity is seen as identity crisis that unfolds the protagonist's lives, and unsuccessful relationships with the other sex. This thesis is manifested through discussions of themes such as identity formation, postcolonial history with questions of migration, and cultural displacement, and motifs such as the return to the motherland, writing journals, and a curse in the family.

The Brief Wondrous Life of Oscar Wao (2008) tackles a specific period of Caribbean history. This period is characterized by violence, atrocity, tyrannical or corrupt leaders and difficult life situations. Oscar Wao's mother migrated from the Dominic Republic to the United States of America. Investigating the causes of migration in the novel is significant as it is closely associated with the protagonists' construction of his national identity. In the novel, the community suffered from the regime of Trujillo in the Dominican Republic. In an important footnote, Diaz (2008) points out:

For those of you who missed your mandatory two seconds of Dominican history: Trujillo, one of the twentieth century's most infamous dictators, ruled the Dominican Republic between 1930 and 1961 with an implacable ruthless brutality. A portly, sadistic, pig-eyed mulato who bleached his skin, wore platform shoes, and had a fondles for Napoleon-era haberdashery, Trujillo (also known as El Jefe, the Failed Cattle Thief, and Fuckface) came to control nearly every aspect of the DR's political, cultural, social, and economic life through a potent (and familiar) mixture of violence, intimidation, massacre, rape, co-operation, and terror; treated the country like it was a plantation and he was the master. (p.3)

Although Oscar did not survive Trujillo's corrupt leadership, his ancestors did such as his grandfather Abelard and his mother, Beli. Abelard used to be one of Trujillo assistants. The dictator Trujillo was known for raping beautiful ladies in the country. Knowing that Abelard's wife and daughter, Jacquelyn, are beautiful and attractive, he invited Abelard to a presidential event and asked for Abelard's wife and daughter to come. Abelard didn't take his wife and daughter to the event, which annoyed Trujillo extremely. As a consequence, and out of anger, Abelard was accused of slander and sentenced to prison for 18 years by Trujillo's authorial law. Trujillo's authority and control were not only limited to the political and social aspects in the country, but they also extended the educational rules and methods in schools and colleges. It was immensely hard for students during his regime to express themselves freely in writings. One of the significant incidents that demonstrated the dictatorship of Trujillo regime is the story of Mauricio Ledesme, one of Beli's classmates. He wrote an essay about his hope to see the Dominican Republic a 
democratic country and exposed one of Turjillo's cruel crime, which is killing Galindez, a scholar and loyalist in the Spanish Civil War. Ledesme was sent out of the country by his family to protect him from any problems because of the essay he wrote about Turjillo.

Beli herself suffered from the regime of Trujillo and was propelled to leave the country involuntarily. She had a relationship with a man called the Gangster, who is the husband of La Fea, Trujillo's sister. The Gangster is also one of Trujillo's closest assistants. Although he promised her a beautiful life and a house in Miami, their relationship was filled with misery more than love. He was absent most of his time for businesses and came for short vacations. When she got pregnant, she was threatened by La Fea and forced by her men to have a miscarriage. Later on, she was kidnapped by Trujillo's men and "they beat her like she was a slave. Like she was a dog ... it was the end of language, the end of hope. It was the sort of beating that breaks people, breaks them utterly" (Diaz, 2008, p. 147). After being rescued by the Mongoose ${ }^{\text {ii }}$, she left for New York when she was only sixteen.

These incidents are significant enough as they show to a great extent how Oscar's ancestors suffered in their homeland and forced to migrate for security and normal life. Oscar's family has become diasporic because of the forms of violence associated with Trujillo's regime. Saez (2011) pointed out that:

Because the formation of the Dominican diaspora was intimately tied to the violence that the Trujillo dictatorship used to forcibly silence opposing voices, Oscar Wao offers itself up as a foundational fiction of the Dominican diaspora, with all of the positive and negative connotations that the term suggests (p.526).

Oscar's diaspora influences him largely and negatively in the United States. These incidents also show to a great extent that their cultural displacement is an involuntary reaction to the violence and lousy life conditions of their homeland. As Hall (1995a) claimed that the Caribbean is a place of "many continuous displacements... The Caribbean people have been destined 'migrate'; it is the signifier of migration itself-of traveling, voyaging" (p. 234).

In addition to the forced or free cultural displacements of the characters in the novel, the protagonist experience conflict with identity formation from childhood till death. Hall (1995a) believed that "the Caribbean people of all kinds, of all classes and positions, experience the question of positioning themselves in a cultural identity as enigma as a problem, as an open question" (p.8). The following analysis focuses on the character's struggle to fit in his new community and how identity crisis colors his lives as the novel unfolds. The attempt of the main character to construct a national identity instead of a hybrid identity in diaspora makes him struggle a lot during his life.

Arab World English Journal for Translation \& Literary Studies 
Throughout the novel, Oscar identifies himself as a Dominican man in the United States of America. He is adamant that he should not divest himself of the Dominican culture and never tries to assimilate to the diverse society and culture in America. His cultural inauthenticity causes him a lot of trouble. He grows up with his mother Beli and sister Lola in New Jersey, Paterson. Diaz (2008) starts his description of Oscar as a boy who never fulfills the stereotype of the "Dominican cats" (p.11). After being dumped by his girlfriend, Maritza, Oscar finds it hard to fit in the stereotypical picture of the Dominican man and suddenly "became synonymous with being a loser with a Capital L. Couldn't make friends for the life of him, too dorky, too shy, and (if the kids from his neighborhood are to be believed) too weird" (Diaz, 2008, p.17). In high school, he feels marginalized and alienated. He starts to gain weight and loses most of his friends. He becomes less social even in parties, he just watches the audience and never enjoys music and dances. His estrangement increases as he develops a tremendous interest in science fiction. His love to scifiction and fantasy has a counter-effect in assimilating himself to the United States for he is continued to be teased by his peers and seen as a weird person. He becomes more isolated. "He had always been a young nerd-the kind of kid who read Tom Swift, who loved comic books and watched Ultraman- but by high school his commitment to the Genres had become absolute" (Diaz, 2008, p. 20). In Rutgers New Brunswick, he insists on emphasizing his Dominican identity. Students look at him differently and treated him badly. Diaz (2008) says:

The white kids looked at his black skin and his afro and treated him with inhuman cheeriness. The kids of color, upon hearing him speak and seeing him move his body, shook their heads. You're not Dominican. And he said, over and over again, But, I am. Soy dominicano. Dominicano soy. (p.49)

As a result, He gains even more weight. His friend Yunior is not satisfied with Oscar's desperation and wants to help him change his life and improve his situation. Yunior tries to help him lose weight and practice running, but Oscar refuses to continue his friend's "Redemption Program" (Diaz,2008, p.179). He fails to make any progress and yells to his friend to leave him alone. His obesity is an embodiment of his self-dissatisfaction, despair, loss, and a key to his cultural inauthenticity. The fact that he accepts people calling him Wao because he dressed in a Halloween party as Oscar Wilde $e^{\mathrm{iii}}$ and heard by his colleague, Melvin, as "Wao" tells so much about his selfcontempt and neglect. He knows that he is going through trouble. His fragmentation influences his self-knowledge and identity. He states: "I don't know what's wrong with me, he said to his sister over the phone. I think the word is crisis" (Diaz, 2008, p.268). The word "crisis" is significant as it shows that Oscar starts to recognize that he has a problem in his life. After graduation, he works as a teacher in his old high school. Usually, teaching position helps build confidence and personal strength. However, Oscar becomes more and more alienated and isolated. He continues to be teased and made fun of. Sadly, this time, it is done by his students whom he educates and helps in building their knowledge. His friend Yunior feels sorry for him saying:

How demoralizing was that? Every day he watched the "cool" kids torture the crap out of the fat, the ugly, the smart, the poor, the dark, the black, the unpopular, the African, the Indian, the Arab, the immigrant, the strange, the 
feminio, the gay-and in every one of these clashes he saw himself" (Diaz, 2008, p.264).

Oscar tries to focus on his writing as a solution to his situation. However, writing occupies his time but doesn't fulfill the vacancy in his self. Yunior says about him:

On the outside, Oscar simply looked tired, no taller, no fatter, only the skin under his eyes, pounced from years of quiet desperation, had changed. Inside, he was in a world of hurt. He saw black flashes before his eyes. He saw himself falling through the air. He knew what he was turning into. He was Turing into the worst kind of human on the planet: an old bitter dork. Saw himself at the Game Room, picking through the miniatures for the rest of his life. He didn't want this future but he couldn't see how it could be avoided, couldn't figure his way out of it. (Diaz, 2008, p.268)

Having outlined how the protagonist's identity crisis affects his life, one might understand that his struggle comes as a result of his inability to assimilate to the culture of the American society and privileging a national identity instead of a hybrid one.

The attempt to form a national identity in diaspora for Oscar is associated with the journey to self-fulfillment. He thinks that women might play a crucial role in his completeness and authenticity. However, by the end of the novel, he agrees that intimacy is what describe love relationships as true. It seems that intimate relationships partially mitigate the struggle the protagonist goes through in his life. To elaborate, Oscar believes that his identity as a Dominican male is largely connected to masculinity. He struggles as the novel unfolds to have a female partner. Oscar's only golden age was when he was seven years old. He had two girlfriends, Maritza and Olga. He rejects Olga because Maritza is more beautiful than Olga, but unfortunately, Martiza rejects him for another boy. Before college, he falls in love with a girl from the Caribbean. She is called Ana Obregon. Oscar was fascinated by the way she looks and they both share an interest in science fiction. When her ex-boyfriend shows up, she breaks up with Oscar. He writes to his sister expressing his sadness: "I have waited forever to be in love ... How many times I thought this is never going to happen to me" (Diaz, 2008, p.47). In college, he falls in love with a girl from Puerto Rico, called Jenni Munoz. She enjoys his company but dumps him for another man. Oscar tries to commit suicide but gets saved by the Mongoose. Saez (2011) highlighted that Oscar is "unable to find a willing partner with whom to engage in sex, his virginity delegitimizes his masculinity and his identity as a Dominican" (p.535). When he goes to Santo Domingo, he falls in love with a middle-aged Dominican woman, called Ybon. Although she is a prostitute, and her first client, called the Captain, a very dangerous man, Oscar falls madly in love with her. His mother and aunt do not approve of Oscar's relationship with Ybon, but he finds in his love to her the intimacy that keeps him move forward in keeping this relationship for as long as he could. When their relationship progresses, the Captain asks his men to handle Oscar. They drive him the cane field and beat him aggressively. Even when he goes back to the United States of America, he can't forget Ybon easily and asks his friend Yunior to lend him money to go back to Santo Domingo. He goes back to meet Ybon for he is obsessed with her. Yunior said "what really got him ... was the little

Arab World English Journal for Translation \& Literary Studies 
intimacies that he'd never in his whole life anticipated ... The beauty! The beauty!" (Diaz, 2008, pp.334-5). Oscar is caught again by the Captain and get killed.

Since relationships with women show the protagonist's struggle with finding intimacy in his life, Oscar feels that searching for essence and roots is a necessary step for national identity formation. Hall (1995a) argues that the question of roots "provides a kind of ground for our identities, something to which we can return, something solid, something fixed, something stabilized around which we can organize our identities and our sense of belongingness" (p.4). Going back home helps Oscar fulfill the vacancy he has in his life and bridge the gap in his identity. However, he faces death tragically there. His death is significant, and it is symbolic in the sense that it shows that constructing a national identity is impossible for him. Speaking of going back to the country of origin, Benitez-Rojo (1996) posited:

Every Caribbean person, after an attempt has been made to reach his culture's origins, will find himself on a deserted beach, naked and alone, coming out of the waters as though shivering and shipwrecked ... without any identification papers other than the uncertain and turbulent memorandum inscribed in his scars, tattoos, and skin color. Finally, every person of the Caribbean is in exile from his own myth and his history, and also from his own culture and his own Being, now and always, in the world. (p.217)

To explain, Oscar, who is desperate to fall in love, finds a woman who reciprocates his feelings, finds love in the Dominican Republic. It has taken Oscar Wao great pains to reach this stage. This event is important as it clearly shows to what extent Oscar cannot bridge the gap in his identity in the United State of America, but in Santo Domingo, he experiences a new kind of life. Instead of being teased for his physical appearance, interests, and hobbies, Oscar's lover, Ybon, finds him an interesting person with multiple talents. Although he fulfills his masculinity, he believes that intimacy is the core of love relationships. This makes him brave enough not to mind losing his life because he feels that intimacy has cured his deep wounds in his identity.

Writing letters or journals is an important motif in the novel. It seems that writing, for Oscar, is an embodiment of self-fulfillment and a way to mitigate the struggle in his identity formation process. Oscar documents his experiences through writing. Oscar's life is told by Yunior as the narrator of the novel. It can be said that Oscar's incapability of narrating his story is related to his struggle in knowing who he is. The readers know about Oscar through Yunior's point of view. However, Oscar documents the last part of his life as letters conveyed to the readers by his friend Yunior. Oscar reveals what happened to him in the plantation field and how he is beaten the first time and the second time until he dies.

The curse is a trauma Oscar has in his family. The curse is a symbolic barrier for Oscar to construct a national identity. On a more general level, the curse stands for the Caribbean trauma of lacking origins and roots. Oscar's family was cursed by fuku' which is associated with Trujillo. Trujillo bestows the curse to Oscar's grandmother because of her disobedience to his policy. His family is cursed, and every single member faces difficulty in forming relationships. His mother 
faces problems in her relationships and she migrates to the United State of America. His sister Lola also faces difficulty in her relationships in the United States of America and sent by her mother back to the Dominican Republic. As it has been mentioned earlier, Oscar fails to attract any woman during his high, senior, and college years. The only successful and real relationship for Oscar is the one that has cost him his life.

\section{Conclusion}

The novel triggers the readers to think that it is a futile project for the Caribbean to demarcate a national identity in diaspora. Hall (1995a) believes that "identity is not in the past to be found, but in the future to be constructed" (p.14). Oscar's main struggle with his identity is derived from a strong connection to his national culture and identity. The novel has certainly enriched the national and hybrid identity formation in diaspora for Caribbean studies.

\section{Endnotes:}

1 - Assimilation as defined by Hall (1999), in his article "Negotiating Caribbean Identities" as: The profound process of assimilation, of dragging the whole society into some imitative relationship with this other culture which one could never quite reach. When one talks about assimilation in the Caribbean, one always feels Caribbean people constantly leaning forward, almost about to tip over, striving to reach somewhere else" (p. 8).

iiDiaz (2008) defines The Mongoose as

One of the great unstable particles of the Universe and also one of its greatest travelers. Accompanied humanity out of Africa and after a long furlough in India jumped ship to the other India, a.k.a. the Caribbean. Since its earliest appearance in the written record-675 B.C.E., in a nameless scribe's letter to Ashurbanipal's father, Esarhaddon - the Mongoose has proven itself to be an enemy of kingly chariots, chains, and hierarchies. Believed to be an ally of Man. Many Watchers suspect that the Mongoose arrived to our world from another, but to date no evidence of such a migration has been unearthed" (p.151).

iii Oscar Wilde (1819-1859) is an Irish poet and playwright. He is known for his The Picture of Dorian Gray (1891), and on his comic masterpieces Lady Windermere's Fan (1892) and The Importance of Being Earnest (1895). He advocated Aestheticism in art during the late $19^{\text {th }}$ century.

\footnotetext{
About the Author:

Samirah Almutairi has a master's degree in literature from King Saud University. She wrote her graduate thesis on Caribbean drama. She worked in Princess Nourah Bin Abdulrahman University and Imam Mohammed Bin Saud University. She taught drama, poetry, advanced writing, and translation. Her ORCID ID is 0000-0002-7065-2579
} 
AWEJ for Translation \& Literary Studies Volume, 4 Number 4. October

\section{References}

Benitez-Rojo, A. (1996). The Repeating Island: The Caribbean and Postmodern Perspective. (Post-Contemporary Interventions). Durham: Duke UP.

Diaz, J. (2008). The Brief Wondrous Life of Oscar Wao. New York: Riverhead Books.

Hall, S. (1990). Cultural Identity and Diaspora. Identity: Community, Culture, Difference. London: Lawrence and Wishart.

Hall, S. (1995a). Negotiating Caribbean Identities. New Left Review1 (209), 3-14.

Retrieved from :https://newleftreview.org/issues/I209/articles/stuart-hall-negotiating-caribbeanidentities

Murdoch, A. (2007). All Skin' Teeth Is Not Grin": Performing Caribbean Diasporic Identity in a Postcolonial Metropolitan Frame. Callaloo, 30 (2), 575-593. Retrieved from: https://www.jstor.org/stable/30129768

O'Callaghan, E. (2010). 'You'll find no finger posts to point you to our place': Mapping The Literary and Critical Terrain. The Journal of West Indian Literature, 18 (2), 20-31. Retrieved from: https://www.jstor.org/stable/23019915

Padley, S. (2006). Key Concepts in Contemporary Literature. Macmillan: Palgrave.

Saez, M. E. (2011). Dictating Desire, Dictating Diaspora: Junot Diaz The Brief Wondrous Life of Oscar Wao as Foundational Romance. Contemporary Literature, 52 (3), 522-555. Retrieved from: https://www.jstor.org/stable/41472506

Said, E. W. (1993). Culture and Imperialism. New York: Vintage Books.

Arab World English Journal for Translation \& Literary Studies 